\title{
Use of microcomputer for histopathology: system using IBM PC and dBaseIII
}

\author{
W M SUEN, K W CHICK \\ From the *Department of Morbid Anatomy, Prince of Wales Hospital, Shatin, Hong Kong
}

SUMMARY A microcomputer program for use in the storage and retrieval of histopathology records is described. The program was written using dBaseIII, a commercially available data management system. The program provides for efficient storage and rapid retrieval of pathology reports and facilitates clinical research. Downloading of data on to a mainframe computer is possible.

The Prince of Wales Hospital, the teaching hospital of the Chinese University of Hong Kong, has 1400 acute beds. The department of morbid anatomy receives about 10000 surgical pathology specimens every year. The manual storage of histopathology reports and their subsequent retrieval is tedious and time consuming. To facilitate filing and retrieval a program based on a desk top microcomputer was designed. We report here our first two years' experience with the system.

\section{Material and methods}

\section{HARDWARE}

An IBM PCXT with 512KB RAM and 10MB hard discs was linked to an EPSON FX-100+ printer. A 32MB external hard disc subsystem (Sigma Designs) was added last year. A streaming tape backup unit with a capacity of $45 \mathrm{MB}$ (Sigma Designs) was used to copy data from the hard disc subsystem.

SOFTWARE

A general database management software, dBaseIII (Ashton-Tate), was used as a basis from which our program-"pathology record system"-was written.

\section{P.W.H. PATHOLOGY RECORD SYSTEM}

1. Input data/Access temporary file.

2. Scan record-by patient's name.

3. Scan record-by hospital number.

4. Scan record-by laboratory number.

5. To PRINT menu.

6. To SEARCH option.

7. Leave this programme, and return to dBASE-III.

8. Leave this programme, and return to SYSTEM. Please list choice.

Fig 1 Main menu of "pathology record system".

\section{PATHOLOGY-NEW RECORD}

\author{
Name: \\ Sex: \\ Age: \\ HKID: \\ Date:YY.MM.DD \\ Lab. no:
}

Tissue:

Please enter laboratory number, otherwise it will not be stored. When you have finished, enter BLANKS for lab. no.

Fig 2 Screen for registration of new specimen (logging in).

\section{PATHOLOGY SIGN-OUT/EDIT}

$\begin{array}{ll}\text { Name: } & \text { LEE YIN KWAN } \\ \text { Sex: } & \text { F } \\ \text { Age: } & 70 \\ \text { HKID: } & \text { NA } \\ \text { Date: } & 86.04 .07 \\ \text { Lab. no: } & \text { S8602637 } \\ \text { Tissue: } & \text { URETHRAL MEATUS }\end{array}$

Diagnosis:

T code:

$M / E / F$ code:

Comment:

Is this report ready for transfer? N

Enter $\mathbf{N}$ for next record, $\mathbf{P}$ for previous record, $S$ for signing-out, $E$ for editing temporary file.

Press RETURN when DONE

Fig 3 Screen for signing out for editing of temporary record. 
P.W.H.DEPT. OF MORBID ANATOMY - SURGICAL PATHOLOGY SUMMARY REPORT

DATE LAB NO. NAME 86.05.14 S8603641 CHOI 86.05.14 S8603642 LEUNG 86.05.14 S8603643 LAU

86.05.14 S8603644 CHOW

86.05.14 $\$ 8603645$ HO

86.05.14 S8603646 CHAN 86.05.14 S8603647 KWONG 86.05.14 S8603648 LEUNG

86.05.14 S8603649 IP

86.05.14 $\$ 8603650 \mathrm{LI}$

86.05.14 $\$ 8603651$ LAU 86.05.14 $\$ 8603652$ TO 86.05.14 S8603653 LEE

86.05.14 S8603654 MOK 86.05.14 S8603655 TSE 86.05.14 S8603656 AU

86.05.14 S8603657 KWOK

86.05.15 S8603658 TAM 86.05.15 S8603659 YU

86.05.15 S8603660 YIP

\begin{tabular}{|c|c|c|c|c|}
\hline SEX & AGE & HKID & TISSUE & DIAGNOSIS \\
\hline F & 41 & B939402 & VABRA ASPIRATION & ENDOMETRIUM-PROLIFERATIVE PHASE \\
\hline & 53 & B254939 & VABRA ASPIRATION & ENDOMETRIUM, PROLIFERATIVE PHASE \\
\hline & 42 & A201557 & ITION & $\begin{array}{l}\text { EARLY SECRETORY ENDOMETRIUM } 9 \text { (PLEASE SEE } \\
\text { ABOVE) }\end{array}$ \\
\hline M & 55 & 16221 & $\begin{array}{l}\text { SUPRACLAVICULAR } \\
\text { LN }\end{array}$ & $\begin{array}{l}\text { METASTATIC ADENOCARCINOMA, POORLY } \\
\text { DIFFERENTIATED }\end{array}$ \\
\hline $\mathrm{M}$ & 32 & E592356 & $\begin{array}{l}\text { R PREAURICULAR } \\
\text { SINUS }\end{array}$ & SINUS TRACT \\
\hline a & 23 & 16954 & APPENDIX & NO HISTOPATHOLOGY \\
\hline & 27 & G154493 & AEVUS OF NECK & SEBORRHOEIC $K$ \\
\hline$F$ & 33 & E471103 & TER & $\begin{array}{l}\text { CHRONIC CERVICITIS. LEIOMYOMA WITH RED REGEN } \\
\text { ERATION }\end{array}$ \\
\hline & 31 & E240544 & NEVUS OF FACE & $\begin{array}{l}\text { INTRADERMAL NEVUS,EXTENDING TO RESECTION } \\
\text { MARGIN }\end{array}$ \\
\hline & 41 & B383584 & UT CURETTINGS & ENDOMETRIUM OF PROLIFERATIVE PHASE \\
\hline A & 20 & C423619 & RT BRE & SYN \\
\hline u & 43 & 2576 & BUTTOCK CYST & EPIDERMAL CYST \\
\hline$r$ & 36 & C280282 & $\begin{array}{l}\text { R BREAST SKIN } \\
\text { NODULE }\end{array}$ & DERMATOFIBROMA \\
\hline & 46 & 0015745 & CERVICAL 3'CLOCK BX & CERVICITIS, ACUT \\
\hline $\mathbf{F}$ & $\begin{array}{l}50 \\
41\end{array}$ & $\begin{array}{l}\text { C134985 } \\
\text { A628848 }\end{array}$ & $\begin{array}{l}\text { VABRA ASPIRATION } \\
\text { CERVICAL, } 40^{\prime} \text { CLOCK }\end{array}$ & $\begin{array}{l}\text { ENDOMETRIUM OF PROLIFERATIVE PHASE } \\
\text { MICROSCOPIC CLUMP OF CELLS SHOWING SEVERE }\end{array}$ \\
\hline $\mathbf{F}$ & 34 & E440827 & CERVIC & $\begin{array}{l}\text { DYSPLASIA (CIN III) } \\
\text { CERVICAL BX AT 1, } 7 \text { AND } 11 \text { O'CLOCK-SEVERE } \\
\text { DYSPLASIA (CIN III) }\end{array}$ \\
\hline A & 68 & & LT & TATIC ADENOCARCINOMA \\
\hline M & 27 & & & $\begin{array}{l}\text { VANT LYMPHOMA, DIFFUSE, SMALL CLEAVED } \\
\text { YPE }\end{array}$ \\
\hline 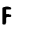 & 69 & 6077539 & LT PARIETAL LOBE & TOMA MULTIFORME \\
\hline
\end{tabular}

T CODE M COOE COMMENT

T28000 M79310

T28000 M79310

T82000 M79320

T08220 M81406 PROBABLE PRIMARY: LUNG

TXY100 M46340

T66000 M00100 TO2300 M72750

$182900 \mathrm{M} 88900$

T02120 M87500

T28000 M79310 T83000 M76800 T08710 M00100

T04020 M71000

T02471 M33410

T02400 M88320

T83000 M42100

T28000 M79310

T83000 M74003

T83000 M74008

TX2200 M81406

TY0100 M96303

TX2300 M94403

Fig 4 Worksheet copy of permanent file.

\section{PROGRAM}

The data file includes the patient's name, hospital number (identity card number), sex, age, date of receiving of the specimen in the laboratory, laboratory number, tissue, diagnosis, topography code, morphology code and comment. The data are stored in two separate files-a temporary file for the logging in of specimens and a permanent file for the final diagnoses. Both topography and morphology codes are manually coded by pathologists with SNOMED (Systematised Nomenclature of Medicine, edited by the College of American Pathologists). Ward and bed number were deliberately omitted due to limited storage capacity. Full reports which include the above data plus detailed descriptions are kept separately.

After several trials we arrived at a menu-driven data entry program (fig 1) which allows secretarial staff with no computing knowledge to key in data. The data are entered in two phases. New specimens are entered into the temporary file which contains the patient's demographic data, date of receipt of specimen, laboratory number, and tissue (fig 2). When the final histopathological diagnosis is available, the diagnosis, SNOMED codes, and comment are added. A flag is then assigned to the record to indicate that the record is ready to be transferred to the permanent file (fig 3). Worksheet hardcopies are printed out periodically from both files in chronological order (fig 4). Transferring records from the temporary to the permanent file is done daily together with the updating of the index files by menu-driven program (fig 5). It takes about 10 to 15 minutes to update 50 records. The updating process is done during off-peak hours.

\section{P.W.H. PATHOLOGY RECORD SYSTEM DATA ENTRY FUNCTION}

1. Log-in new specimen (new record).

2. Sign-out specimen/Edit log-in record.

3. Search record from temporary file- by name.

4. Search record from temporary file- by ID no.

5. Transfer records after sign-out (temporary to permanent) (Warning: This is a time-consuming process).

6. To return to main menu.

Please list choice.

Fig 5 Screen for data entry, editing, and transfer. 
The records are indexed according to the patient's name, hospital number, laboratory number and SNOMED codes. This allows searches to be done quickly: retrieval takes less than five seconds for a file size of 20.000 records.

Backup of data is done with streaming tape on a regular basis by the authors.

\section{Discussion}

We discovered that the introduction of computerisation in our laboratory posed many problems, the least of which was the programming. Resistance from secretarial staff was intense initially, but was quickly overcome as the system proved its value in record retrieval, which greatly assisted the office staff in answering requests from histopathology reports over the phone.

We chose to use the IBM PC because of its popularity. Most of our colleagues possess their own IBM compatible personal computers at home and regularly take data home to work on in floppy discs. Our application program is written in dBaseIII, a very popular and powerful management program. It can handle up to one billion records in up to 128 fields (items); and each field may contain up to 254 characters. Indexing on one or more fields can be done easily. For more advanced programs, one may manipulate up to 15 files at one time. The capacity of this software is obviously more than adequate for a histopathology laboratory. One outstanding feature of dBaseIII is its rapid index search, facilitating almost instantaneous retrieval of data from a very large database. Commands in the program are written in simple English phrases. These are easily mastered with a little practice, even for persons with little or no previous computing knowledge.' Search can also be done on specified variables in any of the fields. Application programs can easily be written. One important feature of the software is that data may be converted into ASCII (American Standard Code for Information Interchange) files, and hence may be downloaded to any standard mainframe computer for data storage or upgrading. This means that record keeping can be started early before planning for a more advanced system, which is known to be time consuming.

To develop our own package on a microcomputer was a challenge. Clinical research and monthly statistics were facilitated by SNOMED coding of the diagnoses. In some centres SNOP was preferred. ${ }^{\prime}$ Our system required the pathologist to code numerically the diagnosis in SNOMED as this gives a specific morphological and aetiological description of the diagnosis. This was time consuming for pathologists, especially in the early phases before they familiarised themselves with the coding. There are packages avail- 음 able for histopathology laboratories, ${ }^{23}$ some even

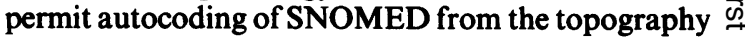
and morphology phases. One such package is the SNOMED system from the College of American 흘 Pathologists (CAP). We were, however, unhappy with the limits such a system imposed on our file structure. $\stackrel{\square}{\Omega}$

Specimens with more than one histopathological \& diagnosis pose certain problems. Our system only $\vec{D}$ allows for the principal diagnosis to be indexed. Additional diagnoses are coded and stored in the "comment" field. Only about $10 \%$ of our specimens have secondary diagnoses, and retrieval of secondary diagnoses is seldom needed in our daily routine work. Although retrieval of those codes is possible by $\vec{i}$ sequential search, it is more time consuming than the index search. Analysis entailing secondary diagnosis $O$ codes, usually for research purposes, can be carried 은 out by running batch files. This can be done at night when the terminal is not needed for data entry or $\mathbb{D}$ enquiries.

The use of mainframe computers to link up clinical laboratories and even the whole hospital is becoming increasingly popular. The installation of a minicomputer for all the clinical laboratories was in the planning stage when we designed our microcomputer system. The ability of our program to download the existing data into the minicomputer was therefore a major consideration. After the minicomputer (Burroughs Computer System) was installed in August 1986 data transfer was successfully accomplished by first transcribing the data into ACSII files, with minor modifications in file structure. Data can also be downloaded from the minicomputer to the personal computer for processing.

We acknowledge the advice and help of Professor J C K Lee.

\section{References}

1 Swettenham KV, Nickols C, Berry CL. Computer programs in histopathology record keeping. J Clin Pathol 1982;35:40-4.

2 Briggs JC, Ibrahim NBN, Mackintosh I, Norris D. Practical use of a word processor in a histopathology laboratory. J Clin Pathol N 1982;35:151-8.

3 Subbuswamy SG, McCormick A, Peters EE. Computerisation of histopathology/cytology records-use of a commercial data storage system. J Clin Pathol 1984;37:157-62.

Requests for reprints to: Dr W M Suen, Department of $\stackrel{9}{?}$ Morbid Anatomy, Prince of Wales Hospital, Shatin, Hong Kong. 